\title{
FIVE DIATOM SPECIES IDENTIFIED BY USING POTENTIAL APPLICATION OF NEXT GENERATION DNA SEQUENCING
}

\author{
Warqaa Yehia Al-Meshhdany* Fikrat M. Hassan** \\ *Institute of Genetic Engineering and Biotechnology for Postgraduate \\ Studies, University of Baghdad, Baghdad, Iraq \\ **Department of Biology, College of Science for Women University of \\ Baghdad, Baghdad, Iraq \\ **corresponding author: fikrat@ csw.uobaghdad.edu.iq
}

Received Date: 28 January 2020; Accepted Date: 06 April 2020; Published Date: 24 June 2020

\section{ABSTRACT}

Molecular barcoding was widely recognized as a powerful tool for the identification of organisms during the past decade; the aim of this study is to use the molecular approach to identify the diatoms by using the environmental DNA. The diatom specimens were taken from Tigris River. The environmental DNA(e DNA) extraction and analysis of sequences using the Next Generation Sequencing (NGS) method showed the highest percentage of epipelic diatom genera including Achnanthidium minutissimum (Kützing) Czarnecki, 1994 (21.1\%), Cocconeis placentula Ehrenberg, 1838 (\%21.3) and Nitzschia palea (Kützing) W. Smith, $1856(16.3 \%)$.

Five species of diatoms: Achnanthidium minutissimum; Fistulifera saprophila (LangeBertalot \& Bonik) Lange-Bertalot, 1997; Gomphonema pumilum (Grunow) E. Reichardt \& Lange-Bertalot, 1991; Navicula veneta Kützing, 1844 and Thalassiosira pseudonana Hasle Heimdal, 1970 were registered in NCBI under the accession numbers as follows: MN749640.1, MN749641.1, MN749642.1, MN749643.1 and MN749646.1 for the first time; while the two algae Fistulifera saprophila and Thalassiosira pseudonana are regarded as a new record to algal flora in Iraq.

The environmental DNA study will be a catalyst for new studies of biodiversity and environmental studies in Iraq and the region.

Keywords: Algae, Diatoms, Edema, Freshwater, NGS, Tigris River.

\section{INTRODUCTION}

Significant environmental problems are caused by rapid population growth in the world; lack of environmental knowledge in society and changes in the industry, particularly during 
Five diatom species identified

the last century. Freshwater habitats are without doubt one of the biosphere elements most impacted by this pollution. Monitoring water quality is therefore essential to the health of the water ecosystem's sustainability and protection (Çiçek et al., 2013; Campbell et al., 2017). Monitoring of water quality by physical and chemical methods is inadequate; in the recent years, particularly in the scientific community, the biological monitoring methods and biological indicator organisms were widely used for effective research (Chang, 2008; Tokatl and Dayığlu, 2011; Adebayo et al., 2013; Berthold et al., 2018).

Diatoms are considered to be a large part of the benthos (often 90-95 percent), and are present all the time in all surface waters. They are also one of the most important groups of aquatic producers and react quickly to the environmental variables change. Diatoms, which are recognized as an important component of bioindicator species, have, therefore, been used as water pollution indicators for environmental assessments in many countries (Gürbüz and Kivrak, 2002; Passy et al., 2004; Godhe and Härnström, 2010; Aydın and Büyükışık, 2014; Tan et al., 2017).

Recently, scientists and researchers can use a basic reality to obtain information and produce more informed choices; this material persists, giving insight into the creature's past and present that left it behind. The eDNA samples were taken from different environments and for that it called environmental DNA (Thomsen and Willerslev, 2015).

During the past decade, molecular barcoding has been widely recognized as a powerful tool for identifying species. The assumption is that there is sufficient information in a short DNA sequence (DNA barcode) to identify the organisms. The major advantage in design studies of the use of DNA barcodes is that standardization and process implementation are simpler than the conventional morphology-based approach (Gao, 2019).

Metabarcoding, which refers to the employment of universal primers for the amplification of DNA from various organisms collected in one sample, is the approach that is most commonly applied in Next Generation Sequencing (NGS) (Taberlet et al., 2012). NGS approaches are being increasingly employed to characterize water-living organisms from the eDNA specimens (Yu et al., 2015).

Current advances in NGS approaches have made it possible to employ molecular barcoding in readily and efficiently investigating the diversity in the environment. The NGS -based environmental monitoring has been shown to be of less time and cost-consuming as compared to the conventional morphology-based methods (Baird and Hajibabaei, 2012). It is important to use the molecular concept as a solution to revise the mis-identification of diatoms and it could be also useful for biodiversity studies (Vasselon et al., 2017). The diatoms identification are often collected as a mixed species in taken sample and this is the main challenges for this purpose (Zimmerma et al., 2015). 
Al-Rawi et al. (2018) reported that the traditional classification is not accurate to identify the algal species in Iraq and confirmed the use of molecular concept to identify algal taxa; Abed et al. (2018) used the molecular concept to identify the algal Coelastrella Chodat, 1922.

This study is aimed to assess the suitability of amplicon sequencing in Next Generation Sequencing (NGS) approach using Illumina platform for identifying epipelic diatoms in the sediment of the Tigris River for the evaluation and development of molecular biological methods in water quality.

\section{Specimens collection}

\section{MATERIAL AND METHODS}

Algal specimens were collected from five sites along the Tigris River from November 2018 to July 2019 (Map 1, Tab. 1); specimens of epipelic were collected randomly by scraping the clay from the surface layer with a depth $0.1-0.5 \mathrm{~cm}$ in area $\left(50 \mathrm{~m}^{2}\right)$ and $(3-5 \mathrm{~mm})$ using a spatula, samples were placed in polyethylene bottles and sample water was added, the bottle was closed and shaken well and placed in a dark place until returning to the laboratory.

Epipelic diatoms were trapped by lens tissues as described by Eaton and Moss (Salman et al., 2017). Epipelic cell was identified after cleaning the silica skeleton by placing the glass slide on a heating plate $\left(75-80^{\circ} \mathrm{C}\right)$, then placing a droplet of the sample on the slide and letto dry completely; followed by a concentrated nitric acid was added on the dry spot and the acid was left to evaporate completely. Then slides were mounted by Canada balsam and the cover was flipped on the dry spot and the lid of the slide was pressed gently to distribute the material in a homogeneous manner to avoid the emergence of bubbles near the edges of the sliding lid (Salman et al. 2017); diatoms were identified according to Round et al (1990).
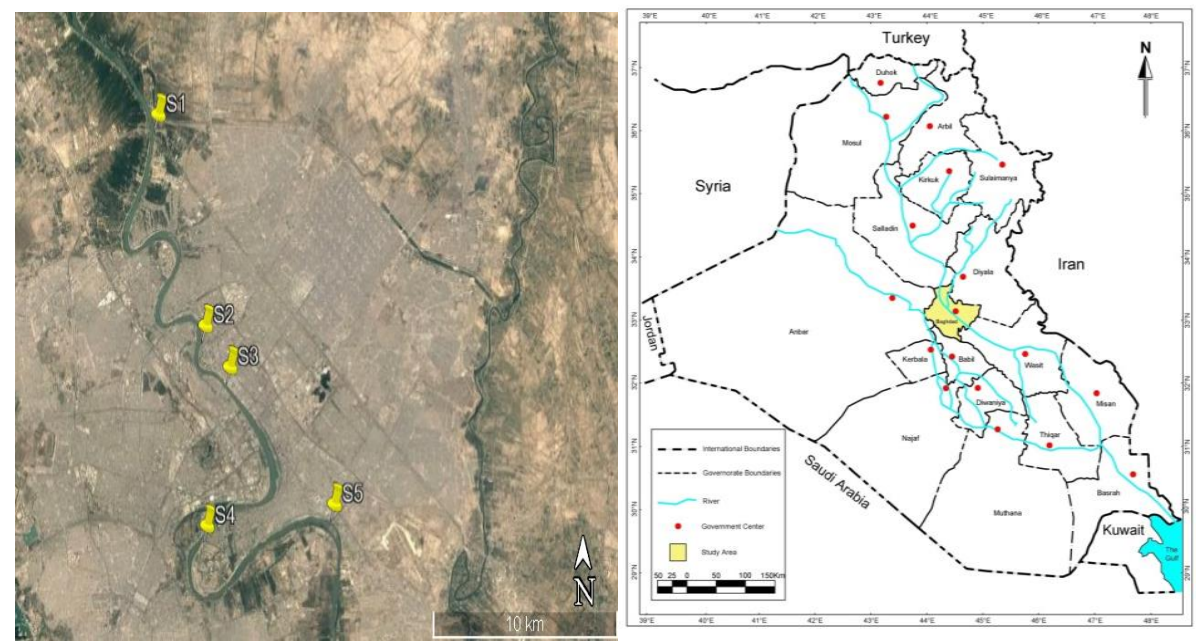

Map (1): Map of study areas (Source: https://earth.google.com). 
Five diatom species identified

Table (1): Geographical positions (GPS) of the five study sites.

\begin{tabular}{|c|c|c|c|c|}
\hline No. & \multirow{2}{*}{ Symbol } & \multirow{2}{*}{ Area } & \multicolumn{2}{|c|}{ Coordinate } \\
\cline { 4 - 5 } & & & North & East \\
\hline $\mathbf{1}$ & $\mathbf{S 1}$ & Al-Muthanna Bridge & $33^{\circ} 25^{\prime} 41.85^{\prime \prime}$ & $44^{\circ} 20^{\prime} 49.63^{\prime \prime}$ \\
\hline $\mathbf{2}$ & $\mathbf{S 2}$ & Al-Sarafiya Bridge & $33^{\circ} 2112.99^{\prime \prime}$ & $44^{\circ} 22^{\prime} 28.77^{\prime \prime}$ \\
\hline $\mathbf{3}$ & $\mathbf{S 3}$ & Al-Shuhadaa Bridge & $33^{\circ} 2019.99^{\prime \prime}$ & $44^{\circ} 23^{\prime} 19.91^{\prime \prime}$ \\
\hline $\mathbf{4}$ & $\mathbf{S 4}$ & Al-Jadriya & $33^{\circ} 16^{\prime} 58.35^{\prime \prime}$ & $44^{\circ} 22^{\prime} 31.87^{\prime \prime}$ \\
\hline $\mathbf{5}$ & $\mathbf{S 5}$ & Al-Zafraniya & $33^{\circ} 17^{\prime} 25.44^{\prime \prime}$ & $44^{\circ} 26^{\prime} 58.23^{\prime \prime}$ \\
\hline
\end{tabular}

\section{Culturing of diatoms}

Diatoms were cultured by using the purchase F2 medium following Guillard (1975)method. Each epipelic diatom cell suspension was inoculated with 20 to $250 \mathrm{ml}$ off $/ 2+0.025 \mathrm{SiO}_{3}$ medium gradually, the culture was incubated under cycles of illumination with $12 \mathrm{~h} / 12 \mathrm{~h}$ light-dark and constant temperatures $20^{\circ} \mathrm{C}$ (Al-Hussieny et al., 2014).One $\mathrm{ml}$ of culture was transferred to $1.5 \mathrm{ml}$ tubes in the exponential growth phase (14-20 days of incubation), and the sample was centrifuged at $4000 \mathrm{xg}$ for ten minutes. In the final step, the supernatant was discarded and the resulted pellets were stored at $-20{ }^{\circ} \mathrm{C}$, this step is to freeze the pellet in order to block the action of the enzymes like RNAase and protease. The pellets were kept for further use as recommended by Visco et al. (2015).

\section{Molecular identification of Diatoms}

In order to identify unknown diatoms at a molecular base, four genes were selected (XXXX) (Tab. 2). Primers were designed and manufactured in Macrogen company laboratories (Seoul, South Korea).

Table (2): Primers design used in this study.

\begin{tabular}{llll}
\hline Genes & Primer Sequence FWD $3^{*}-5^{\circ}$ & Primer Sequence Re $3^{\prime}-5^{\circ}$ & Reference \\
\hline ITS3-ITS4 & GCATCGATGAAGAACGCAGC & TCCTCCGCTTATTGATATGC & $\begin{array}{l}\text { Moniz and Kaczmarska } \\
(2010)\end{array}$ \\
18S V4F-V4R & CCAGCAGCCGCGGTAATTC & ACTTTCGTTCTTGATTAA & Luddington et al. (2012) \\
18S V9F-V9R & CCCTGCCHTTTGTACACAC & CCTTCYGCAGGTTCACCTAC & Luddington et al. (2012) \\
$\begin{array}{l}\text { D2 } 2 \text { 3 of LSU } \\
\text { rRNA }\end{array}$ & ACAAGTACCGTGAGGGAAAGTTG & TCGGAAGGAACCAGCTACTA & Hamsher et al. (2011) \\
\hline
\end{tabular}

\section{Genomic DNA manipulation:}

For DNA purification, the genomic DNA of 20 isolated samples of unknown diatoms were extracted according to the protocol of QIAamp DNA Mini Kit, QIAGEN, and the isolated DNA was subjected to PCR (Gene Amp, PCR system 9700; Applied Biosystem) according to manufacturer's instructions. 


\section{Multiplex polymerase chain reaction (PCR)}

The total volume of PCR amplification reaction was performed $25 \mu$ land included10ng/ $\mu$ l DNA, (1X) Taq PCR PreMix (Intron, Korea), and $1 \mu \mathrm{M}$ of each primer, and then distilled water was added into the tubes. Conditions of the thermal cycling containing denaturation at $95{ }^{\circ} \mathrm{C}$ for $5 \mathrm{~min}$, were followed by 30 cycles of $95^{\circ} \mathrm{C}$ for $30 \mathrm{~s}, 60{ }^{\circ} \mathrm{C}$ for $30 \mathrm{~s}$ and $72{ }^{\circ} \mathrm{C}$ for $30 \mathrm{~s}$, with a final incubation at $72{ }^{\circ} \mathrm{C}$ for $7 \mathrm{~min}$ using a thermal Cycler (Gene Amp, PCR system 9700; Applied Biosystem). The PCR products were separated by $2 \%$ agarose gel electrophoresis and visualized by exposure to ultraviolet light $(302 \mathrm{~nm})$ after staining with red stain (Intron Korea). For PCR products, $10 \mu \mathrm{l}$ was directly loaded into the well. Electrical power was turned on at 100v/m Amp for 75 minutes and DNA was migrating from the Cathode to plus Anode poles. Ethidium bromide-stained bands in gel were visualized using gel imaging system.

For standard genes sequencing, PCR amplification of $18 S$ rRNA products of all isolated diatoms was sent to macrogen company laboratories for sequencing using the Illumina platform by Next Generation Sequencing (NGS) workflow, which includes 4 basic steps.

\section{Calculating Phred Quality Scores (Q scores)}

$\mathrm{Q}$ scores are a measure of the quality of the identification of the nucleobase generated by automated DNA sequencing, that is logarithmically related to the base call error probabilities (P)(Ewing and Green,1998).

$\mathrm{Q}=-10 \log 10^{\mathrm{P}}$

\section{RESULTS AND DISCUSSION}

A total of 186 epipelic diatoms taxa were identified according to the traditional concept (by compound microscopy model GX-140105) which belong to a 59 genera according to (Round et al., 1990). The most abundant taxa are illustrated in Table (3). 
Five diatom species identified

Table (3): The most abundant diatomic taxa (identified by compound microscope) during the study period.

\begin{tabular}{|l|l|}
\hline Classes & Taxa \\
\hline Bacillariophycaeae & Achnanthidium minutissimum (Kutzing) Czarnecki \\
\cline { 2 - 3 } & Cocconeis placentula Ehrenberg \\
\cline { 2 - 3 } & C. placentula var. euglypta (Ehrenberg) Grunow \\
\cline { 2 - 2 } & Gomphonema gracile Ehrenberg \\
\cline { 2 - 2 } & Nitzschia frustulum var. minuta Pantocsek \\
\cline { 2 - 2 } & Rhopalodia musculus (Kützing) O.Müller \\
\hline Fragilariophyceae & $\begin{array}{l}\text { Fallacia enigmatica } \text { (H. Germain) Lange-Bertalot \& } \\
\text { Werum }\end{array}$ \\
\cline { 2 - 2 } & Fragilaria intermedia (Grunow) Grunow \\
\cline { 2 - 2 } & F. pygmaea (Kützing) A. J. Stickle \& D.G.Mann \\
\hline & Aulacoseira granulata (Ehrenberg) Simonen \\
\cline { 2 - 2 } & Melosira varians C.Agardh \\
\cline { 2 - 2 } & Pantocsekiella ocellata (Pantocsek) K.T.Kiss \& E.Ács \\
\hline
\end{tabular}

Characterization of Diatoms by $18 S$ rRNA and eDNA

To unequivocally determine the diatoms in sediment samples, diatoms were isolated by two means through $18 S$ rRNA and eDNA. The gene of interest was screened for $18 S r R N A$ using different primer pairs (Table 4).The resulted PCR products of $18 S r R N A$ were obtained from unknown samples and analyzed on $2 \%$ agarose gel and subsequently sequenced by NGS. The PCR products were (778bp) for A. minutissimum, (877 bp) for F. saprophila, (1110 bp) G. pumilum, (679bp) N. veneta, and (484 bp) for T. pseudonana (Pl. 1).

Table (4): Data Statistics for diatoms.

\begin{tabular}{|l|l|l|l|l|l|l|}
\hline Genes & $\begin{array}{l}\text { Total read } \\
\text { bases (bp) }\end{array}$ & Total reads & GC (\%) & AT (\%) & $\begin{array}{l}\text { Q20 } \\
(\%)\end{array}$ & Q30 (\%) \\
\hline 18S_V9FV9R & $94,387,580$ & 313,580 & 47.957 & 52.04 & 77.987 & 72.456 \\
\hline D2D3_LSU & $98,594,356$ & 327,556 & 50.856 & 49.14 & 89.683 & 78.397 \\
\hline ITS3_ITS4 & $102,630,164$ & 340,964 & 43.632 & 56.37 & 95.028 & 88.079 \\
\hline
\end{tabular}




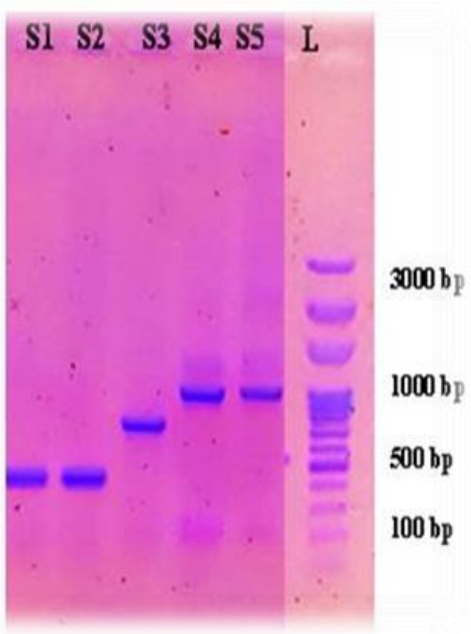

Plate (1):PCR products were electrophoresed on a $2 \%$ agarose gel $(2 \mathrm{~h} ., 5 \mathrm{~V} / \mathrm{cm}, 1 \mathrm{X}$ TBE$)$ and visualized under U.V. light after staining Lane: L (M: 100bp ladder, S: sample. Lane S1, S2, S3, S4 and S5 represent the PCR products of isolated diatoms.

In Illumina MiSeq by NGS, the sequencing generated total number of bases sequenced, and total number of reads sequences, quinine- cytosine (GC \%) content and adenine - thymine (AT\%). As is explained table (4). While the high quality of the phred score for each gene sequences with an average Q20\% and Q30\% was illustrated in Diagram (1).

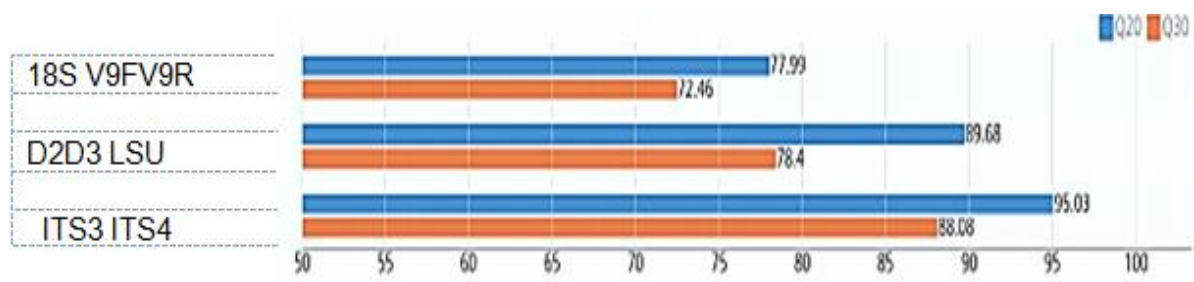

Diagram (1): Quality values line about sequences of the three genes with Q20/Q30 scores of sequences data.

The following diatom species were obtained with the relative abundance by the laboratories of Macrogen Corporation laboratories in Korea using Illumina platform by NGS for each DNA samples. These samples were identified by a three encoding genomic sequence described in previous table 2. A. minutissimum and $C$. placentula were diagnosed with the highest relative abundance with a slight difference (21.1 and 21.3\%), respectively, followed by $N$. palea with a percentage $(16.3 \%)$, while the least abundance diatom was recorded for $N$. $c f$. frustulum with abundance of $(0.7 \%)$ (Tab. 5). 
Five diatom species identified

Table (5): Relative abundance of diatom species by NGS

\begin{tabular}{|c|c|c|}
\hline Taxa & Proportion (\%) & Notes \\
\hline Achnanthidium minutissimum & 21.1 & $\begin{array}{c}\text { For the first time identified by } \\
\text { molecular analysis in Iraq }\end{array}$ \\
\hline Amphora montana & 1.6 & \\
\hline Cocconeis placentula & 21.3 & \\
\hline Cyclotella meneghiniana & 2.3 & \\
\hline Fistulifera saprophila & 1.9 & New record in Iraq \\
\hline Fragilaria pinnata & 2.9 & \\
\hline Gomphonema parvulum & 9.8 & \\
\hline Gomphonema pumilum & 9.6 & $\begin{array}{l}\text { For the first time identified by } \\
\text { molecular analysis in Iraq }\end{array}$ \\
\hline Nitzschia amphibia & 1.4 & \\
\hline Nitzschia cf. frustulum & 0.7 & \\
\hline Nitzschia palea & 16.3 & \\
\hline Navicula veneta & 3.4 & $\begin{array}{c}\text { For the first time identified by } \\
\text { molecular analysis in Iraq }\end{array}$ \\
\hline Thalassiosira pseudonana & 4.34 & $\begin{array}{l}\text { Unclear. } \\
\text { pseudonana is considered } \\
\text { widespread. It is known from } \\
\text { freshwater habitats (Kiss, 1984). } \\
\text { New record in Iraq } \\
\text { Confirm by Prof. Dr.Bahram K. } \\
\text { Maulood (personal } \\
\text { communication, March 14, 2020) }\end{array}$ \\
\hline Ulnaria ulna & 3.36 & \\
\hline
\end{tabular}

The NGS sequencing were aligned online using Basic Local Alignment Search Tool (BLAST) at the National Center for Biotechnology Information (NCBI). The 18S rRNA sequence of all diagnostic diatom samples showed 99\% homology with other global diatoms registered in the NCBI under the accession numberin NCBIMN602030.1, MH997844.1, AM501970.1, KU900218.1, KC736629.1, respectively. The sequence analysis, types of polymorphism, location of nucleotide of $18 S$ rRNA gene for isolated diatoms were shown in Table (6) and demonstrated in (Diags. 2, 6). 
Al-Meshhdany and Hassan

Table (6): Types of polymorphism of $18 S \mathrm{rRNA}$ gene from isolated diatoms.

\begin{tabular}{|c|c|c|c|c|c|c|c|}
\hline $\begin{array}{l}\text { No. of } \\
\text { sample }\end{array}$ & $\begin{array}{c}\text { Type of } \\
\text { substitution }\end{array}$ & Location & Nucleotide & Sequence ID & Score & Identities & Taxa \\
\hline \multirow{7}{*}{1} & Transition & 762 & $\mathbf{G}>\mathbf{A}$ & ID:MN602030.1 & 1372 & $99 \%$ & \multirow{7}{*}{$\begin{array}{c}\text { Achnanthidium } \\
\text { minutissimum }\end{array}$} \\
\hline & Transition & 977 & $\mathbf{A}>\mathbf{G}$ & & & & \\
\hline & Transvertion & 1211 & $\mathbf{C}>\mathbf{G}$ & & & & \\
\hline & Transition & 1231 & $\mathbf{G}>\mathbf{A}$ & & & & \\
\hline & Transition & 1250 & $\mathbf{A}>\mathbf{G}$ & & & & \\
\hline & Transvertion & 1354 & $\mathbf{T}>\mathbf{G}$ & & & & \\
\hline & Transition & 1365 & $\mathbf{A}>\mathbf{G}$ & & & & \\
\hline \multirow{4}{*}{2} & Transition & 554 & $\mathbf{A}>\mathbf{G}$ & ID:H997844.1 & 1564 & $99 \%$ & \multirow{4}{*}{$\begin{array}{l}\text { Fistulifera } \\
\text { saprophila }\end{array}$} \\
\hline & Transvertion & 556 & $\mathbf{T}>\mathbf{A}$ & & & & \\
\hline & Transition & 671 & $\mathbf{A}>\mathbf{G}$ & & & & \\
\hline & Transvertion & 886 & $\mathbf{C}>\mathbf{A}$ & & & & \\
\hline \multirow{6}{*}{3} & Transvertion & 556 & $\mathbf{T}>\mathbf{G}$ & ID:M501970.1 & 1198 & $99 \%$ & \multirow{6}{*}{$\begin{array}{l}\text { Navicula } \\
\text { veneta }\end{array}$} \\
\hline & Transvertion & 711 & $\mathbf{T}>\mathbf{G}$ & & & & \\
\hline & Transvertion & 735 & $\mathbf{T}>\mathbf{G}$ & & & & \\
\hline & Transition & 765 & $\mathbf{A}>\mathbf{G}$ & & & & \\
\hline & Transition & 792 & $\mathbf{T}>\mathbf{C}$ & & & & \\
\hline & Transvertion & 849 & $\mathbf{G}>\mathbf{C}$ & & & & \\
\hline 4 & Transition & 785 & $\mathbf{A}>\mathbf{G}$ & ID:KU900218.1 & 869 & $99 \%$ & $\begin{array}{c}\text { Thalassiosira } \\
\text { pseudonana }\end{array}$ \\
\hline \multirow{2}{*}{5} & Transvertion & 711 & $\mathbf{G}>\mathbf{C}$ & ID:KC736629.1 & 1994 & $99 \%$ & \multirow{2}{*}{$\begin{array}{c}\text { Gomphonema } \\
\text { pumilum }\end{array}$} \\
\hline & Transvertion & 923 & $\mathbf{G}>\mathbf{C}$ & & & & \\
\hline
\end{tabular}


Five diatom species identified

Achnanthidium minutissimum strain (18S rRNA) gene, partial sequence. Sequence ID:MN602030.1 Length: 1651Number of Matches: 1

Range 1: 644 to 1421Genbank Graphics Next Match Previous Match

$\begin{array}{lllll}\text { Score } & \text { Expect } & \text { Identities } & \text { Gaps } & \text { Strand } \\ \text { 1372 bits(1521) } & \mathbf{0 . 0} & \mathbf{7 7 1 / 7 7 8 ( 9 9 \% )} & \mathbf{0 / 7 7 8 ( 0 \% )} & \text { Plus/Plus }\end{array}$

Query61GTTCAAAGCAGGCTTATGCCGTTGAATGTCTTAGCATGGAATAATAAGAT AGGACCTTAG120

||||||||||||||||||||||||||||||||||||||||||||||||||||||||||

Sbjct704

GTTCAAAGCAGGCTTATGCCGTTGAATGTCTTAGCATGGAATAATAAGATAGGAC CTTGG763

Query301

CCATCGTAGTCTTAACCATAAACTATGCCGACAGGGGATTGGTGGGGTTTCGTTA CGTCT360

|||||||||||||||||||||||||||||||||||||||||||||||||||||||||||

Sbjct 944

CCATCGTAGTCTTAACCATAAACTATGCCGACAAGGGATTGGTGGGGTTTCGTTA CGTCT1003

Query541

TCTTTCTTGATTCTATGGGTGGTGGTGGATGGCCGTTCTTAGTTGGTAGAGTGATT

TGTC600

|||||||||||||||||||||||||||||||||||||||||||||||||||||||||||

Sbjct1184TCTTTCTTGATTCTATGGGTGGTGGTGCATGGCCGTTCTTAGTTGGTGGA GTGATTTGTC1243

Query601

TGGTTAGTTCCGTTAACGAACGAGACCGCTGCCTGCTAAATAGTCCAGTGAGTGA ATTTC660

||||||||||||||||||||||||||||||||||||||||||||||||||||||||||

Sbjct1244TGGTTAATTCCGTTAACGAACGAGACCGCTGCCTGCTAAATAGTCCAGT GAGTGAATTTC1303

Query661

ACTGACGAGGACTTCTTAGAGGGACGTGCGTTCTATTAGACGCAGGAAGAGAGC

GGCAAT720

|||||||||||||||||||||||||||||||||||||||||||||||||||||||||||

Sbjct1304ACTGACGAGGACTTCTTAGAGGGACGTGCGTTCTATTAGACGCAGGAAG ATAGCGGCAAT1363

Query721

AGCAGGTCTGTGATGCCCTTAGATGTTCTGGGCCGCACGCGCGCTACACTGATGC ATT778

||||||||||||||||||||||||||||||||||||||||||||||||||||||| 
Sbjct1364AACAGGTCTGTGATGCCCTTAGATGTTCTGGGCCGCACGCGCGCTACAC TGATGCATT1421

Diagram (2): Sequences analysis of $18 S$ rRNA gene for Achnanthidium minutissimum.

Fistulifera saprophila isolate HYU-D033 small subunit ribosomal RNA gene, partial sequence, Sequence ID: MH997844.1 Length: 1654Number of Matches: 1

Range 1: 305 to 1181 Genbank Graphics Next MatchPrevious Match

$\begin{array}{lllll}\text { Score } & \text { Expect } & \text { Identities } & \text { Gaps } & \text { Strand } \\ \text { 1564 bits(1734) } & \mathbf{0 . 0} & \mathbf{8 7 3 / 8 7 7 ( 9 9 \% )} & \mathbf{0 / 8 7 7 ( 0 \% )} & \text { Plus/Plus }\end{array}$

Query241

CGTAGTTGGGTATGTGGTGTGCGTTGCGGCGTCCATTTGTTTGGTTCTGCCGTGAC CGCG300

|||||||||||||||||||||||||||||||||||||||||||||||||||||||||

Sbjct545

CGTAGTTGGATTTGTGGTGTGCGTTGCGGCGTCCATTTGTTTGGTTCTGCCGTGAC

CGCG604

Query361

CTGTGAGAAAATTAGAGTGTTCAAAGCAGGCTTATGCCGTTGAATATATTAGCAT

GGAAT420

|||||||||||||||||||||||||||||||||||||||||||||||||||||||||||

Sbjct665

CTGTGAAAAAATTAGAGTGTTCAAAGCAGGCTTATGCCGTTGAATATATTAGCAT

GGAAT724

Query541

GAACTACTGCGAAAGCATTTACCAAGGATGTTTTCATTAATAAAGAACGAAAGTT

AGGGG600

||||||||||||||||||||||||||||||||||||||||||||||||||||||||||

Sbjct 845

GAACTACTGCGAAAGCATTTACCAAGGATGTTTTCATTAATCAAGAACGAAAGTT

AGGGG904

Diagram (3): Sequences analysis of $18 S$ rRNA gene for Fistulifera saprophila

Naviculaveneta18S rRNA gene, strain AT-108Gel01 Sequence ID: AM501970.1

Length: 1745Number of Matches: 1

Range 1: 492 to 1170GenBank Graphics Next Match Previous Match

Score Expect Identities Gaps Strand

1198 bits(1328) $\quad 0.0 \quad 673 / 679(99 \%) \quad 0 / 679(0 \%) \quad$ Plus/Plus

Query61CAGCGCCAATAGCGTATATTAAAGTTGTTGCAGTTAAAAAGCTCGTAGTT GGATTTGTGG120 
Five diatom species identified

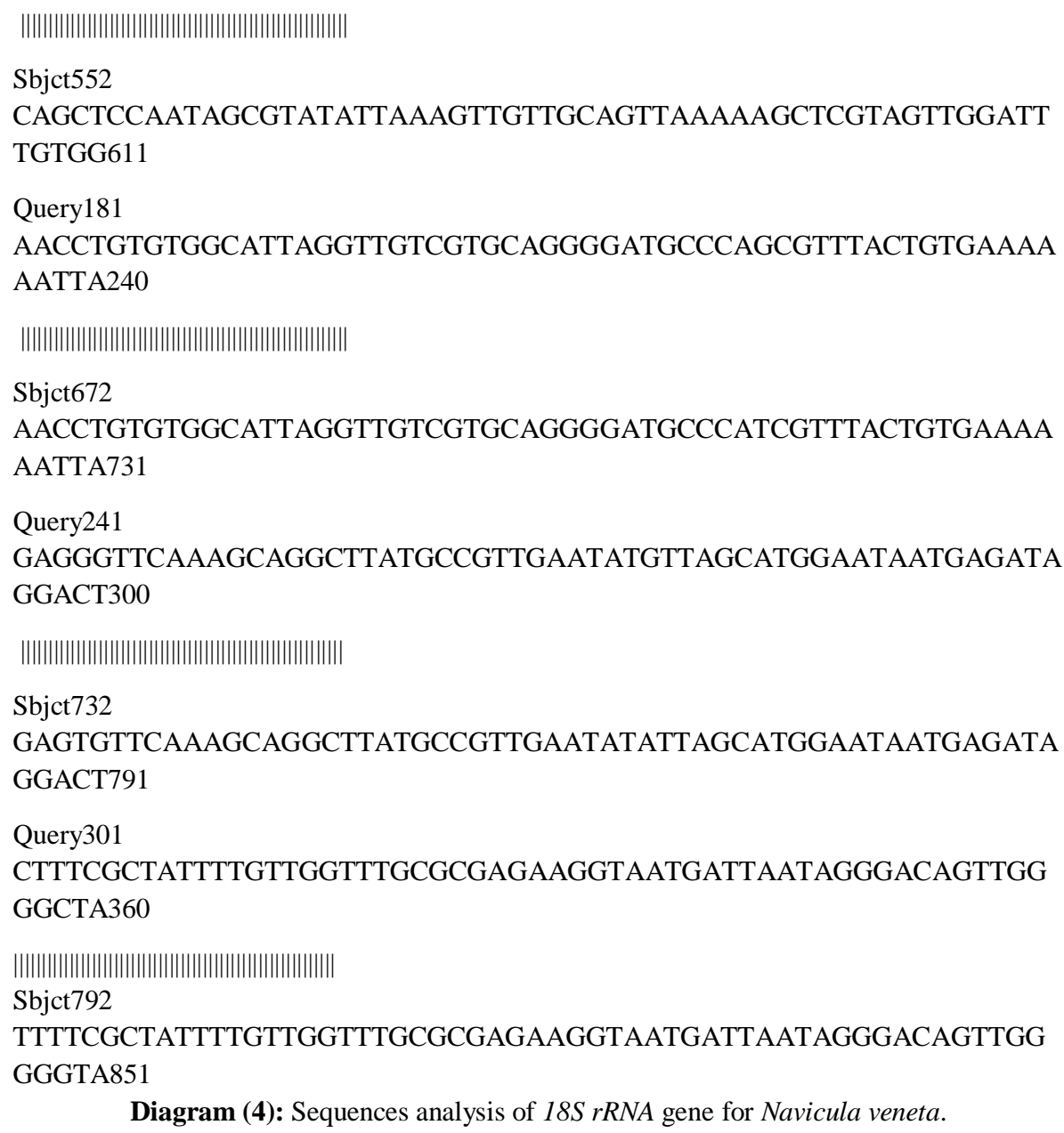

Diagram (4): Sequences analysis of $18 S$ rRNA gene for Navicula veneta.

Thalassiosira pseudonana strain CCAP 1085/12 18S ribosomal RNA gene, partial sequence, Sequence ID: KU900218.1 Length: 1755Number of Matches: 1

Range 1: 615 to 1098GenBankGraphics Next Match Previous Match

$\begin{array}{lllll}\text { Score } & \text { Expect } & \text { Identities } & \text { Gaps } & \text { Strand } \\ \text { 869 bits }(963) & 0.0 & 483 / 484(99 \%) & \mathbf{0 / 4 8 4 ( 0 \% )} & \text { Plus/Plus }\end{array}$

Query121

GGGATACCCATCGTTTACTGTGAAAAAATTAGAGTGTTTAAAGCAGGCTTGTGCC GTTGA180

|||||||||||||||||||||||||||||||||||||||||||||||||||||||||| 
Sbjct735

GGGATACCCATCGTTTACTGTGAAAAAATTAGAGTGTTTAAAGCAGGCTTATGCC GTTGA794

Diagram (5): Sequences analysis of $18 S$ rRNA gene for Thalassiosira pseudonana.

Gomphonema pumilum clone TCC536 18S ribosomal RNA gene, partial sequence

Sequence ID: KC736629.1 Length: 1683Number of Matches: 1

Range 1: 255 to 1364 GenBank Graphics Next Match Previous Match

$\begin{array}{lllll}\text { Score } & \text { Expect } & \text { Identities } & \text { Gaps } & \text { Strand } \\ 1994 \operatorname{bits}(2210) & 0.0 & 1108 / 1110(99 \%) & 0 / 1110(0 \%) & \text { Plus/Plus }\end{array}$

Query421

ACGTTTACTGTGAAAAAATCAGCGCGTTCAAAGCAACCTTATGCTGTGAATGTAT

TAGCA480

|||||||||||||||||||||||||||||||||||||||||||||||||||||||||||

Sbjct675

ACGTTTACTGTGAAAAAATCAGCGCGTTCAAAGCAAGCTTATGCTGTGAATGTAT

TAGCA734

Query661

TAGGGGATCCAAGATGATTAGATACCATCGTAGTCTTAACCATAAACTATGCCGA

CAAGG720

||||||||||||||||||||||||||||||||||||||||||||||||||||||||||

Sbjet 915

TAGGGGATCGAAGATGATTAGATACCATCGTAGTCTTAACCATAAACTATGCCGA

CAAGG974

Diagram (6): Sequences analysis of $18 S$ rRNA gene for Gomphonema pumilum.

\section{NGS data analysis}

The results were analyzed using genius software. Sequencing of genes was performed by the Seoul National Instrumentation Center for Environmental Management (SNU NICEM) online at: http:/www.mbio.ncsu.edu/bioedit/bioedit.html, using a DNA sequencer 3730XL by Applied Biosystem. A homology search was conducted using Basic Local Alignment Search Tool (BLAST) program which is available at the National Center Biotechnology Information (NCBI) online at http://www.ncbi.nlm.nih.gov and software BioEditPro. Version: 7.0.0 program. An expected value is defined to give an estimation of the number of times expected to get the same similarity coincidental and the lower the value of expecting. This indicates that the degree of similarity was high between sequences which give greater confidence; a value close to zero means that these sequences are identical and the Bit Score, which is a statistical measure of the sequence similarity and the higher value indicates a high degree of similarity. Isolated diatom samples were confirmed by sequence-based phylogenetic tree (aligned sequences were conducted using MEGA 6 program) structuring analysis using $18 \mathrm{~S}$ ribosomal RNA (18SrRNA) gene sequencing in Diagrams (7-11). 
Five diatom species identified

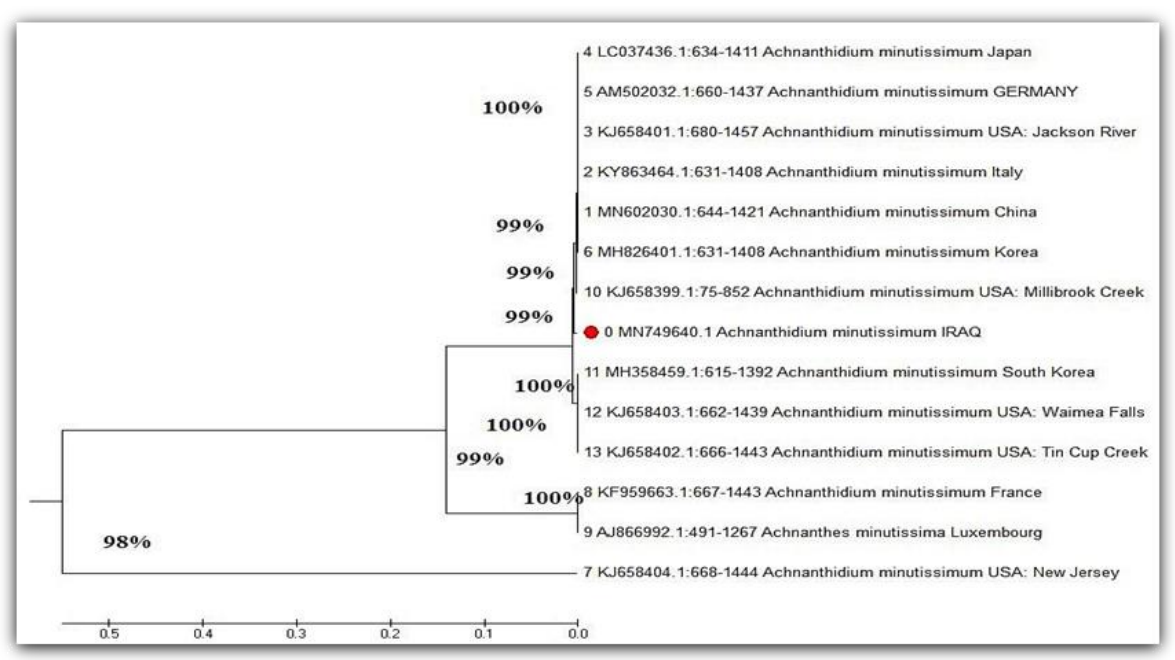

Diagram (7): Phylogenetic tree of Achnanthidium minutissimum based on $18 S$ rRNA gene sequences conferred by GeneBank data base, were analyzed and aligned through BLAST from NCBI using the Neighbor-Joining Analyses of 778bp of corresponding position of $18 S$ rRNA gene sequence. MEGA 6 program was used for phylogenetic tree.

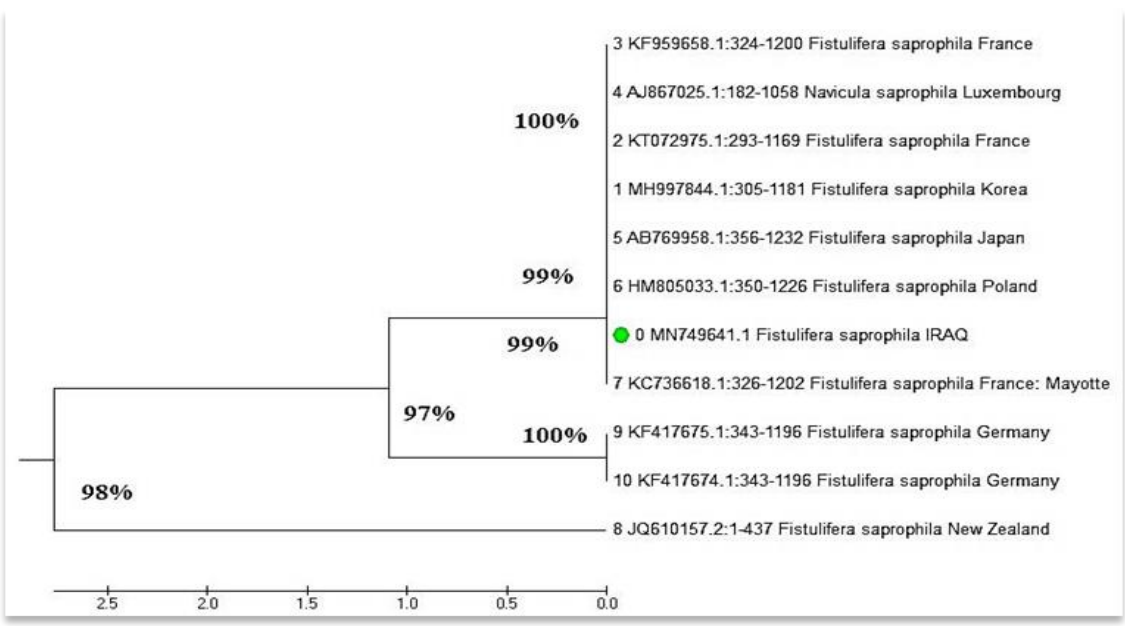

Diagram (8): Phylogenetic tree of Fistulifera saprophila based on 18S rRNA gene sequences conferred by GeneBank data base, were analyzed and aligned through BLAST from NCBI using the Neighbor-Joining Analyses of $877 \mathrm{bp}$ of corresponding position of $18 S$ rRNA gene sequence. MEGA 6 program was used for phylogenetic tree. 
Al-Meshhdany and Hassan

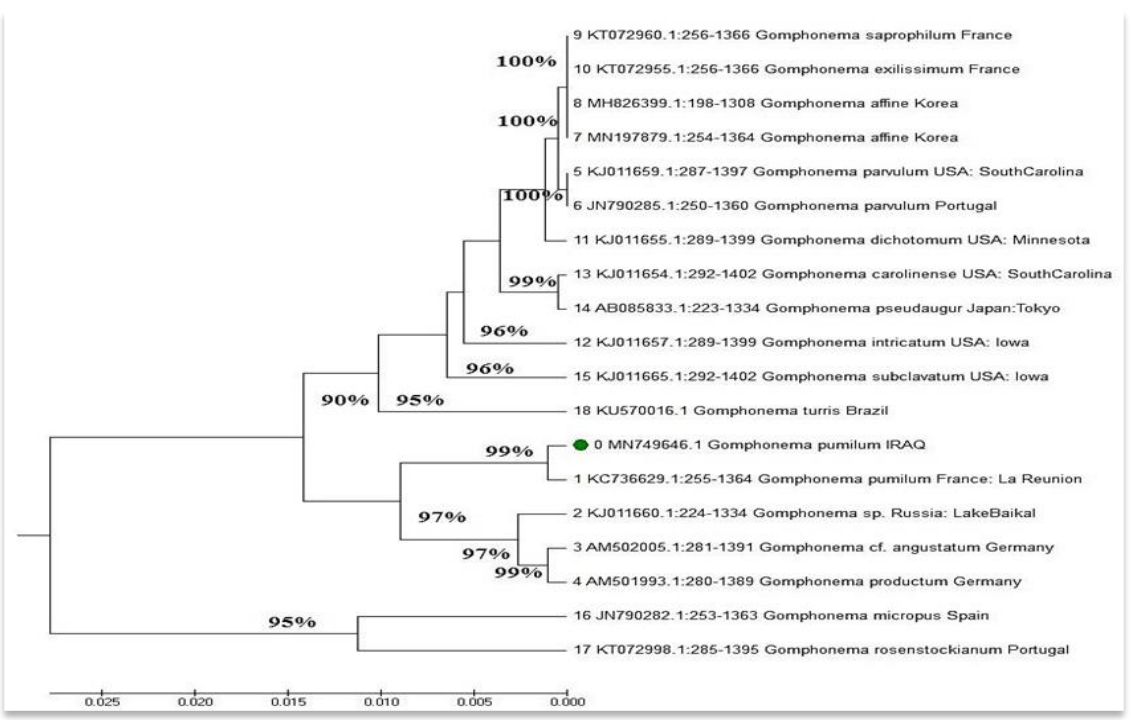

Diagram (9): Phylogenetic tree of Gomphonema pumilum based on $18 S$ rRNA gene sequences conferred by GeneBank data base, were analyzed and aligned through BLAST from NCBI using the Neighbor-Joining Analyses of $1110 \mathrm{bp}$ of corresponding position of $18 S$ rRNA gene sequence. MEGA 6 program was used for phylogenetic tree.

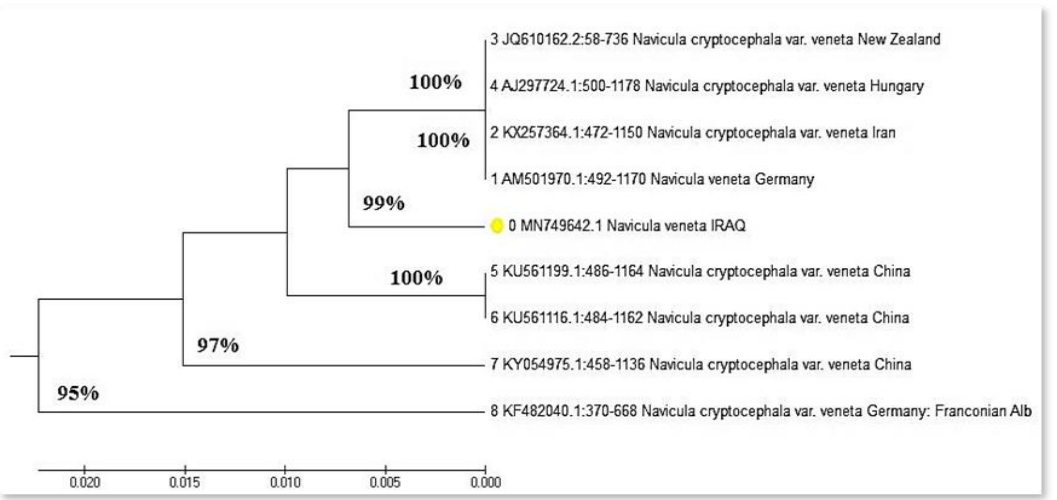

Diagram (10): Phylogenetic tree of Naviculaveneta based on $18 S$ rRNA gene sequences conferred by GeneBank data base, were analyzed and aligned through BLAST from NCBI using the Neighbor-Joining Analyses of $679 \mathrm{bp}$ of corresponding position of $18 \mathrm{~S} r R N A$ gene sequence. MEGA 6 program was used for phylogenetic tree. 
Five diatom species identified

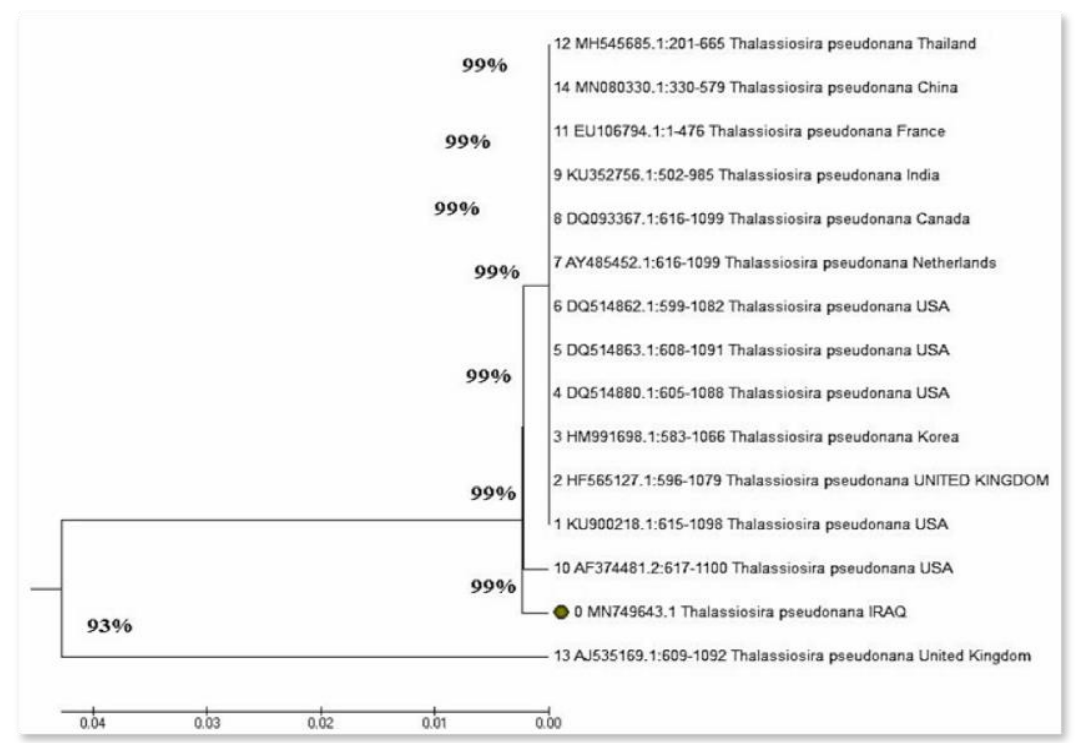

Diagram (11): Phylogenetic tree of Thalassiosira pseudonana based on $18 S$ rRNA gene sequences conferred by GeneBank data base, aligned together with yeast, were analyzed and aligned through BLAST from NCBI using the Neighbor-Joining Analyses of $484 \mathrm{bp}$ of corresponding position of $18 \mathrm{~S} r R N A$ gene sequence. MEGA 6 program was used for phylogenetic tree.

The molecular analysis revealed five diatom species which were identified for the first time by molecular analysis, while two species were recorded as new species of Iraqi algal flora and were registered in NCBI under the accession number as follows:

(1) Achnanthidium minutissimum (accession numberMN749640.1).

(2) Fistulifera saprophila (accession number MN749641.1) new record.

(3) Gomphonema pumilum (accession number MN749642.1).

(4) Navicula veneta (accession number MN749643.1).

(5) Thalassiosira pseudonana (accession number MN749646.1) new record.

By comparing Phylogenetic tree of A. minutissimum with neighboring countries, it was $99 \%$ closer to China. When compared, Phylogenetic tree of $F$. saprophila turned out to be more similar 99\% to the ID number diagnosed in Korea. The Phylogenetic tree for the species $G$. pumilum was more closely related to the registration number that was diagnosed in France as 99\%.The affinity ratio was $99 \%$ phylogenetic tree of $N$. veneta with registration number ID: AM501970.1 which registered in Germany. Phylogenetic tree of T. pseudonana based on $18 \mathrm{~S}$ $r R N A$ gene sequences conferred by GeneBank data base, were analyzed and aligned through 
BLAST from NCBI using the Neighbor-Joining Analyses and was also 99\% recorded in the USA.

The morphological and molecular (phylogenetic) determination of diatomic organisms is another potential conflict source. Firstly, there is a range of genetically distinctive forms that reflect almost all morphospecies. Secondly, some species have their own auto-ecological values subdivided into subspecies or morphological varieties. In the first case, a significant benefit for biomonitoring may be the cryptic diversity, especially when cryptic species relate to certain specific ecological conditions. The second case is more troubling because the subspecific taxa are generally not genetically characterized (Visco et al., 2015).

The quantitative analysis of NGS data gives the greatest challenge in efforts to alleviate biases in the calculation of diatom indices. In fact, numerous NGS environmental studies display contradiction between the number of sequences assigned to a given species and the number of specimens of the same species in microscopic preparations (Gibson et al., 2014) or even microbially diverse communities (Amend et al., 2010). This unbalance correlation between the multiple reading and individuals could be interpreted either by technical biases introduced during DNA extraction, PCR amplification or sequencing or by biological factors such as the variations of rRNA gene copies (Weber and Pawlowski, 2013; Pawlowski et al., 2014), which may depend on number of nuclei in genome size, or variety in size of cell (Prokopowich et al., 2003; Heyse et al., 2010).

The results given in this experience study will need validation by more NGS-based surveys of diatom diversity. Indeed, substantial efforts must be done by diatom taxonomists and biologists to complete the DNA barcoding reference database and to determine the rate of genetic and morphological differences in diatom species.

A total of 186 taxa were identified of epipelic algae by microscopy (Tab. 3), whereas only a few of identified epipelic (5.4\%) were observed by using molecular analysis in this study (Tab. 5). While Amphora montana, Fistulifera saprophila, Nitzschia cf. frustulum and Thalassiosira pseudonana were detected by molecular analysis and not identified by microscopy. Another study also observed only $19 \%$ of identified diatoms by using molecular analysis while they identified 63 taxa by microscopy (Vasselon et al., 2017). Vasselon et al. (2017) mentioned that about $68 \%$ of diatom species identified by microscopy were incomplete in the reference database; moreover, it is important to use suitable DNA extraction methods. This finding will encourage the researcher to use the molecular analysis for identifying algae in the environment. These diatoms were found in freshwater habitats and reorganized in different regions worldwide (Reichardit, 1997; Wojtal, 2003, Novais et al., 2015).

\section{CONCLUSION}

The use of molecular concept of classification is important to re-check the list of the algal flora in Iraq to confirm or to amend them. The application of eDNA revealed five diatom species were a new record species of Iraqi algal flora and it will be a catalyst for new studies 
Five diatom species identified

of biodiversity and environmental studies in Iraq and the region. The molecular application will resolve the misclassification and the persistent problems of misidentification of algae. Moreover, the NGS will decrease the period of the specimen process with using automation of the protocols of molecular works and led to the increase in the number of sampling, in addition to reduce the cost of this tech.

\section{ACKNOWLEDGMENTS}

Authors thank the department of Biology, College of Science and Iraqi Hereditary company for the facilities support and they extend their thanks to Asst. Prof. Dr. Halah Al- Haideri and Asst. Prof. Dr. Safa Al-Deen A. Al-Qaysi for their comments on the manuscript.

\section{LITERATURE CITED}

Abed, I. J., Abdulhasan, G. A. and Najem, A. M. 2018. Genotype versus phenotype to determine the definitive identification of the genera Chlorella Berjinck, 1890 (Chlorophyceae) and Coelastrella Chodat, 1922 (Scenedesmaceae). Bulletin of Iraq Natural History Museum, 15 (1):101-111.

Adebayo, O. O., Sangodoyin, A.Y., Ogedengbe, K., and Taiwo, O. 2013. Mapping of river water quality using inverse distance weighted interpolation in Ogun-Osun river basin, Nigeria. Acta Geographica Debrecina Landscape and Environment, 7 (2): 48-62.

Al-Hussieny, A. A., Hussein, H. T. and Hmood, A. H. 2014. Propagation of algae farms using several methods by different farming media. Journal of the College of Basic Education, 20 (84/Scientific): 121-142.

Al-Rawi, A., Alwash, B. M. J., Al-Essa, N. E. and Hassan, F. M. 2018. A new record of Coelastrella terrestris (Reisigle) Hegewald \& N. Hangata, 2002 (Sphaeropleales, Scenedesmaceae) in Iraq. Bulletin of Iraq Natural History Museum, 15 (2): 153-161.

Amend, A. S., Seifert, K. A., Bruns, T. D. 2010. Quantifying microbial communities with 454 pyrosequencing: does read abundance count? Molecular ecology, 19(24): 5555-6565.

Aydın, G. Ș. and Büyükıșık, B. 2014. Effects on the species-specific variables nutrient pulses: Thalassiosira allenii (Takano). Journal of Tekirdag Agricultural Faculty, 11(3): 8290.

Baird, D. J. and Hajibabaei, M. 2012. Biomonitoring 2.0: a new paradigm in ecosystem assessment made possible by next-generation DNA sequencing. Molecular Ecology, 21(8): 2039-2044.

Berthold, M., Karsten, U., von Weber, M., Bachor, A. and Schumann, R. 2018. Phytoplankton can bypass nutrient reductions in eutrophic coastal water bodies. Ambio, 47(1): 146-158. 
Campbell, B. M., Beare, D.J., Bennett, E. M., Hall-Spencer, J. M., Ingram, J. S., Jaramillo, F., Ortiz, R., Ramankutty, N., Sayer, J. A. and Shindell, D. 2017. Agriculture production as a major driver of the Earth system exceeding planetary boundaries. Ecology and Society, 22(4): 1-8.

Chang, H. 2008. Spatial analysis of water quality trends in the Han River basin, South Korea. Water Research, 42 (13): 3285-3304.

Çiçek, A., Bakiş, R., Uğurluoğlu, A., Köse, E. and Tokatli, C. 2013. The effects of large borate deposits on ground water quality. Polish Journal of Environmental Studies, 22(4): 1031- 1037.

Ewing, B. and Green, P. 1998. Base-calling of automated sequencer traces using phred. II. Error probabilities. Genome Research, 8(3):186-194.

Gao, Z., Wang, X., Wei, X., Liu, Y. and Han, J. 2019. DNA Mini-Barcoding: A Derived Barcoding Method for Herbal Molecular Identification. Frontiers in plant science, 10: 987.

Gibson, J., Shokralla, S., Porter, T. M., King, I., van Konynenburg, S., Janzen, D. H., Hallwachs, W. and Hajibabaei, M.2014. Simultaneous assessment of the macrobiome and microbiome in a bulk sample of tropical arthropods through DNA metasystematics. Proceedings of the National Academy of Sciences, 111(22): 80078012.

Godhe, A. and Härnström, K. 2010. Linking the planktonic and benthic habitat: genetic structure of the marine diatom Skeletonema marinoi. Molecular Ecology, 19(20): $4478-4490$.

Guillard, R. R. 1975. Culture of phytoplankton for feeding marine invertebrates. In: Smith, W. L., Chanley, M. H. (eds), Culture of marine invertebrate animals (pp. 29-60). Springer, Boston, MA.

Gurbuz, H. and Kivrak, E. 2002. Use of epilithic diatoms to evaluate water quality in the Karasu River of Turkey. Journal of Environmental Biology, 23(3): 239-246.

Hamsher, S. E., Evans, K .M., Mann, D. G., Poulíčková, A. and Saunders, G. W. 2011. Barcoding diatoms: exploring alternatives to COI-5P. Protist, 162 (3): 405-422.

Heyse, G., Jönsson, F., Chang, W.J. and Lipps, H.J. 2010. RNA-dependent control of gene amplification. Proceedings of the National Academy of Sciences, 107(51): 2213422139. 
Five diatom species identified

Kiss, K. T. 1984. Occurrence of Thalassiosira pseudonana Hasle et Heimdal (Bacillariophyceae) in some rivers of Hungary. Act Botiunica Hungarica, 30 (3-4): 277-287.

Luddington, I.A., Kaczmarska, I. and Lovejoy, C. 2012. Distance and character-based evaluation of the V4 region of the 18S rRNA gene for the identification of diatoms (Bacillariophyceae). PLoS ONE, 7 (9): e45664.

Moniz, M. B. and Kaczmarska, I. 2010. Barcoding of diatoms: nuclear encoded ITS revisited. Protist, 161(1): 7-34.

Novais, M. H., Juettner, I., Van de Vijver, B., Morais, M. M., Hoffmann, L. and Ector, L. 2015. Morphological variability within the Achnanthidium minutissimum species complex (Bacillariophyta): comparison between the type material of Achnanthes minutissima and related taxa, and new freshwater Achnanthidium species from Portugal. Phytotaxa, 224 (2): 101-139.

Passy, S. I., Bode, R. W., Carlson, D. M. and Novak, M. A. 2004. Comparative environmental assessment in the studies of benthic diatom, macroinvertebrate, and fish communities. International Review of Hydrobiology: A Journal Covering all Aspects of Limnology and Marine Biology, 89 (2): 121-138.

Pawlowski, J., Lejzerowicz, F. and Esling, P. 2014. Next-generation environmental diversity surveys of foraminifera: preparing the future. The Biological Bulletin, 227(2): 93-106.

Prokopowich, C. D., Gregory, T. R. and Crease, T. J. 2003. The correlation between rDNA copy number and genome size in eukaryotes. Genome, 46(1): 48-50.

Reichardit, E. 1997. Taxonomic revision of species complex of Gomophonema pumilum (Bacillariophyceae). Nova Hedwigia, 65:99-130.

Round, F. E., Crawford, R. M. and Mann, D. G. 1990. The Diatoms. Morphology and biology of the genera. Cambridge University Press, Cambridge, UK, ix+747 pp.

Salman, J. M., Hassan, F. M. and Baiee, M. A. 2017. Practical methods in environmental and pollution laboratory. Issued by Environmental Research Center, University of Babylon. ISBN2463.

Taberlet, P., Coissac, E., Pompanon, F., Brochmann, C. and Willerslev, E. 2012. Towards next-generation biodiversity assessment using DNA metabarcoding. Molecular ecology, 21(8): 2045-2050. 
Tan, X., Zhang, Q., Burford, M. A., Sheldon, F. and Bunn, S. E. 2017. Benthic diatom based indices for water quality assessment in two subtropical streams. Frontiers in microbiology, 8: 601 .

Thomsen, P.F. and Willerslev, E. 2015. Environmental DNA-An emerging tool in conservation for monitoring past and present biodiversity. Biological Conservation, 183: 4-18.

Tokatlı, C. and Dayığlu, H. 2011. Use of epilithic diatoms to evaluate water quality of Murat Stream (Sakarya River Basin, Kütahya): different saprobity levels and $\mathrm{pH}$ status. Journal of Applied Biological Sciences, 5(2): 55-60.

Vasselon, V., Domaizon, I., Rimet, F., Kahlert, M. and Bouchez, A. 2017. Application of high-throughput sequencing (HTS) metabarcoding to diatom biomonitoring: Do DNA extraction methods matter?. Freshwater Science, 36(1): 162-177.

Visco, J. A., Apothéloz-Perret-Gentil, L., Cordonier, A., Esling, P., Pillet, L. and Pawlowski, J. 2015. Environmental monitoring: inferring the diatom index from next-generation sequencing data. Environmental Science and Technology, 49 (13): 7597-7605.

Weber, A. A. and Pawlowski, J. 2013. Can abundance of protists be inferred from sequence data: a case study of Foraminifera. PloS ONE, 8 (2): e56739.

Wojtal, A. 2003. Diatoms of the genus Gomphonema Ehr. [Bacillariophyceae] from a karstic stream in the Krakowsko-Czestochowska Upland. Acta Societatis Bot Anicorum Poloniae, 72 (3): 213- 220.

Yu, L., Zhang, W., Liu, L. and Yang, J. 2015. Determining microeukaryotic plankton community around Xiamen Island, southeast China, using Illumina MiSeq and PCRDGGE techniques. PLoS ONE, 10(5): e0127721

Zimmerman, J., Glöckner, G., Jahn, R., Enke, N. and Gemeinholzer, B. 2015.. Metabarcoding vs. morphological identification to assess diatom diversity in environmental studies. Molecular Ecology Resources, 15(3):526-42. 
Bull. Iraq nat. Hist. Mus.

(2020) 16 (1): 39-61.

$$
\begin{aligned}
& \text { تشخيص خمسة انواع دايتومية باستعمال التطبيقات الممكنة لتسلسل الحمض } \\
& \text { النووي البيئي دن الجيل النالي } \\
& \text { ورقاء يحيى المشهداني* و فكرت مجيد حسن* } \\
& \text { *معهدالهندسية الور اثية و التقنيات الاحيائية للار اسات العليا، جامعةبغداد، } \\
& \text { بغداد، العراق الاهبان } \\
& \text { **قسم علوم الحياة، كليةالعلوم للبنات، جامعتبغداد، بغداد، العراق }
\end{aligned}
$$

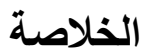

عرفت تشفير الباركود بشكل واسع كأداة قوية لتحديد الكائنات الحية خلال العقد الماضي. لذلك هدفت الدراسة الحالية لاستخدام المفهوم الجزيئي لتحديد

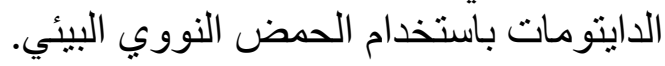

اخذت العينات الدايتومات من نهر دجلة، اذ بينت نتائج استخلاص وتحليل تسلسل الحمض النووي البيئي من خلال استخدام تسلسل الجيل التالي (NG)

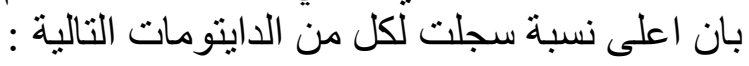
(21.1\%) Achnanthidium minutissimum (Kützing) Cocconeis placentula Ehrenberg, g Czarnecki, 1994 Nitzschia palea (Kützing) W. Smith, $\quad$ g(\%21.3)1838 1856 بنسبة 16.3\%

سُجلتن خمسة اجناس للايتومات لاول مرةفي المركز الوطني لمعلومات

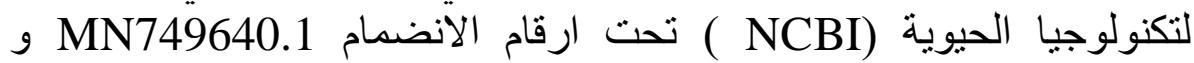
و MN749643.1 و MN749642.1 و MN749641.1

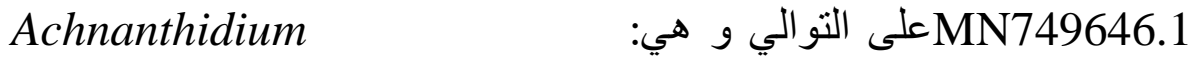
Fistulifera saprophila (Lange-Bertalot \& g minutissim Gomphonema pumilum , Bonik) Lange-Bertalot, 1997 Navicula g (Grunow) E. Reichardt \& Lange-Bertalot, 1991 
Al-Meshhdany and Hassan

Thalassiosira pseudonana Hasle , veneta Kütz. 1844

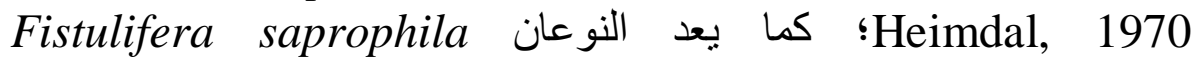
و Thalassiosira pseudonana تسجيلا جديدا للفلورا الطحلبية في

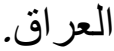

تعتبر دراسة الحمض النووي البيئي عاملا مساعدا في اجر اء دراسات جديدة حول التنوع البيولوجي و الدراسات البيئة في العراق والئل الدنطقة. 